\title{
The Literacy Needs of Adolescents in Their Own Words
}

\section{By featuring the stories of}

seven students, the authors

of this article hope to prompt

administrators and teachers

to examine the literacy

instruction in their schools

and make practical changes

to meet adolescents' needs.
Sharon M. Pitcher | Gilda Martinez | Elizabeth A. Dicembre | Darlene Fewster | Montana K. McCormick

$\mathrm{O}$ ver the last few years, we have noted an increase in the amount of adolescents seeking literacy help through our university reading clinic. The majority of these students need comprehension instruction focused on learning to apply strategies when reading, which is a national trend (Alvermann, 2003; Biancarosa \& Snow, 2004). Although we are seeing these problems in our assessments, some of the students were achieving proficient or above on state reading assessments. Others are in reading programs focused on phonics instruction. Therefore, we decided to thoroughly examine the reading needs of adolescent students coming to the reading clinic to better understand the problem.

Seeking understanding of this disparity and realizing the far-reaching problems these low literacy levels will cause, we assembled an investigative team with research experience in adolescent literacy, English-language learners (ELLs), special education, secondary education, parent involvement, and curriculum development to look at the data from different perspectives. Together, the team has over 75 years of experience working in different roles in school systems. We sought to reach beyond the boundaries of the university to design research to explore the problem.

\section{Significance of the Problem}

Biancarosa and Snow (2004) reported that approximately eight million adolescents struggled with reading. The National Endowment for the Arts (2007) found that "little more than a third of high school seniors now read proficiently" (p. 13). The U.S. Department of Education suggested that "reading ability is a key predictor of achievement in mathematics and science, and the global information economy requires today's American youth to have far more advanced literacy skills than those required by any previous generation" (Kamil et al., 2008, p. 1). Alvermann (2003) suggested resisting the temptation to "fix" learners and instead address the learning conditions to meet 
their needs. She cautioned against schools focusing on finding a "magic bullet" (p. 2). Researchers have also voiced concerns that external pressures and mandates force teachers to work in classrooms where they have little say in how they are teaching (Alvermann, 2003; Santa, 2006).

In 1999, the International Reading Association's position statement on adolescent literacy suggested that adolescents deserve access to a wide range of materials, instruction that includes both skill development and motivation, assessment that shows their strengths as well as needs, instruction in comprehension strategies, and reading specialists to help struggling readers (Moore, Bean, Birdyshaw, \& Rycik, 1999). Ten years later, we see little of these recommendations being met in the schools surrounding our university. Instead, scripted, one-size-fits-all programs are being put in place or students are receiving no intervention at all. Also, reading specialists are either not available or are required to use the assessments and instruction provided with the scripted reading programs.

The study described in this article sought to examine the needs of adolescent readers. To accomplish this and to extend information from previous studies, the researchers examined the contexts that foster adolescents' reading motivation, connections between their current literacies and academic literacies, and their needs as readers as suggested by research (Guthrie \& Humenick, 2004; National Governors Association, 2005; Pitcher et al., 2007).

\section{Procedures}

\section{Objectives of the Study}

Our objectives were to investigate the following research questions: (a) What types of reading instruction are adolescent students receiving? (b) Are the adolescents in this study receiving the type of instruction that they need? and (c) Do parents understand what kind of reading instruction their children need and what role to play in their adolescents' reading education?

To answer these questions, we examined the needs of seven adolescent students who attended the university reading clinic for 12 weeks in the spring of 2008. The students were tested with assessments, including QRI-4 (Leslie \& Caldwell, 2006), the Lexia Comprehensive Reading Test (Lexia Learning Systems, 2004), and the Adolescent Motivation to Read Survey-R (Pitcher et al., 2007), and interviewed. Their parents were also interviewed using questions that paralleled the student interview. In addition we researched the reading programs that the students and parents stated were currently used for instruction to examine the programs' components and determine how the programs met their needs. The students all lived in the Baltimore metropolitan area, attended different types of schools (except one that was homeschooled), were in grades 6 through 8 , were all experiencing some reading difficulties, and were from various ethnic, cultural, religious, and socioeconomic backgrounds.

\section{Methodology}

This study used a collection of case studies to analyze whether reading/literacy programs are meeting adolescents' individual needs. Seven adolescents were assessed one-on-one to find out what motivated them to read, their word identification levels, their comprehension levels, and which reading strategies they used to comprehend text. Next, members of the research team interviewed both the students and their parents to help establish the answers to the research questions. This follows the recommendations of Conley and Hinchman (2004), who suggested that adolescents "can contribute immeasurably to diagnoses of their literacy-related needs" (p. 44). The curriculum used by the schools was determined through a review of multiple sources, such as websites, interviews with parents, and information from teachers in the respective school systems.

Then, the researchers individually analyzed the cases using the constant comparative method to determine recurring themes (Bogdan \& Biklen, 2002). Next, the team met to compare themes. Finally, using mutually agreed upon themes, the team developed snapshots of each student to examine similarities and differences, including quotes from the students and their parents. Conclusions about how the reading instruction met the adolescents' literacy needs were determined through data triangulation of the interviews, assessments, and review of curriculum 
documents. The conclusions across all of the cases were then examined to determine recurring themes crucial to understanding the needs of all the students. All names in the following snapshots are pseudonyms.

\section{The Student Snapshots}

\section{Case 1: Tamika}

Tamika, originally from South Africa, is in sixth grade in a public school and is an ELL. She participates in a reading intervention class in her school using Language! (Greene, 1996), a scripted program focused on phonics, decoding, and spelling. The method of instruction she encounters in content area classes is assigned readings and answering questions. Tamika enjoys math class best because there is not much reading involved. However, she spends around five hours a day on the computer, reading and writing e-mails, updating her website, and playing games. Tamika stated that she did not have any problems reading on the computer. When asked, "What kind of difficulties are you having when you read?" Tamika responded, "Understanding what the topic is about."

Tamika was not receiving comprehension instruction in school. Her mother concurred that her greatest difficulty is reading comprehension: "The difficulties my daughter is having is the comprehension part. She can read, she can spell, but the comprehension part for some reason is hard for her." Her mother stated that she was not invited to a parent conference because Tamika was supposedly doing "okay." She went on to explain that Tamika was placed in the Language! class as a result of one test, and she was notified via mail of this placement. Her mother believed this program was not challenging her daughter, and she would have valued conferencing with the teacher. Therefore, she brought Tamika to the reading clinic, sharing that she struggles with comprehension and is not motivated to read.

From assessments administered in the reading clinic, we determined that Tamika's comprehension is on the second-grade level, whereas her word recognition is at the sixth-grade level-her current grade placement. Her strengths included sight word recognition, word identification, and awareness of her own reading needs. Tamika's needs included vocabulary development and during-reading strategies. Comparing her needs with the school's instruction, there seems to be a disconnect between the two. The school's reading program focuses on decoding strategies, grammar, and spelling, whereas she needs vocabulary development and comprehension.

Tamika's reading clinic instruction focused on using before-, during-, and after-reading strategies while reading and summarizing text. Visual organizers, sticky note strategies, and chunking text were used. She applied all of the techniques she learned to whatever text she read. She also learned to use games to help her learn new vocabulary. This helped her monitor her own understanding of what she read.

\section{Case 2: Karl}

Karl is in seventh grade and homeschooled. He was diagnosed with attention deficit disorder when he was in public school and had an individual education plan (IEP). He received pull-out reading support in elementary school. When asked what reading he enjoys, he shared that he enjoys reading on his porch and likes to keep up with current events using Google. Karl indicated that reading and thinking aloud help him understand what he reads. He spends about three hours a day on the computer e-mailing friends, using MySpace, and reading the news. When asked if reading is ever a problem on the computer, his response was simply, "Uh, no."

Karl's father said Karl's mother, not a trained teacher, homeschools him to ensure instruction matches his needs. She uses a homeschool curriculum, consisting of reading and answering questions, and supplements the curriculum with reading and researching online. Karl asserted that self-selected readings and journaling are helpful. His parents enrolled him in the reading clinic to improve his reading comprehension and writing skills. From the assessments, we determined that his word recognition and comprehension were both on the second-grade level. He was motivated to read self-selected texts. His needs included decoding, vocabulary, fluency, and comprehension. He did not use before-, during-, or afterreading strategies.

The clinic instruction focused on teaching him to make connections to improve comprehension. His 
teacher concentrated on making predictions, thinking aloud, and visualizing strategies. Both the teacher and his parents reported that his understanding of what he was reading improved considerably during this short amount of instruction.

The curriculum his parents use with Karl focuses more on practicing reading than learning strategies. Homeschooling in Maryland receives very little oversight by the Maryland State Department of Education. Students are not required to take state assessments, and parents only meet with the student's zoned public school once a year to show the curriculum used.

\section{Case 3: Kathy}

Kathy is an eighth grader in a suburban school system. She enjoys riding horses, playing the piano, playing basketball on a team, and acting in a community theater group. She wants to be a librarian; the library is her favorite place to go, because she can choose any book she wants.

Kathy was diagnosed with autism at a young age and has received special education services throughout her school years. In middle school, she receives smallgroup, pull-out help in reading daily, provided by a special educator. The school's reading intervention program, Corrective Reading (Engelmann, Carnine, \& Johnson, 1999), focuses mostly on auditory phonics development, with comprehension primarily concentrated in answering recall questions. The instruction in this program is mostly teacher centered with little independent application. She does not get any reading support in her content area classes. She maintained that she has the most trouble understanding what she reads in science class but receives no support with that class. She further stated that in elementary school she had opportunities to choose books, but this is not done in her middle school. When asked about what helps her to read, she answered, "When I was in elementary school, I read, like, different kinds of stories in different books."

Kathy uses the computer at home for a variety of activities. She has many pen pals and writes them letters. She enjoys making bookmarks with clip art she finds on the Internet to give to special people as gifts. When she wants to know something, she looks it up on the Internet. She has even learned to shop online, because she really does not like to go to stores. She stated that she seems to understand more of what she reads on the computer than she does in print texts.

Kathy's parents shared their frustration that the school will not recognize that the computer can help Kathy learn. They feel it would distract her and did not include any computer use on her IEP. The times that the parents tried to
Kathy's parents want to partner with Kathy's school, but they continually receive resistance from the school's faculty. fight this, their input was ignored. Her father shared, "Here's the window to this child, and no one can take advantage of it. At 3 years old, we sat her down in front of the computer, and now she writes her own stories."

Both of Kathy's parents are very knowledgeable about her educational needs. From the time she was very young, they researched autism, sought professional help, and used many methods to help her at home. Her mother shared that Kathy needs a very visual, kinesthetic learning approach, which is why the computer interaction has been successful. Her mom is also concerned about her limited vocabulary, stating that Kathy needs to make connections with words in context rather than "just reading a definition on paper."

Kathy's parents want to partner with Kathy's school, but they continually receive resistance from the school's faculty. Her father remarked that "they can't answer the hard questions." Since her parents are very conscious of her needs, they have been very frustrated with the scripted reading program being used in Kathy's school. Her father serves on the advocacy group for parents of special education students in their county school system. When he researched the reading program that is being used in the county, he discovered that it is not research based, focuses on word identification with very weak vocabulary and comprehension components, is predominantly auditory based, and has no computer component. When he shared this with teachers, he got "the deer in the headlights stare."

Our findings agreed with Kathy's parents' conclusions. Kathy's word recognition was on the sixth-grade level, but her comprehension was on 


\section{The school's reading}

program not only

did not fit Kathy's

needs but also was

incongruent with her

learning style. a first-grade level. When asked about reading strategies, she could not verbalize any. Her strength, though, was writing. She wrote in correct, well-developed sentences with correct capitalization, punctuation, and grammar.

Kathy's reading clinic teacher reported that she made connections when reading strategies were taught using pictures, writing, and story maps. Vocabulary definitely got in her way, but expanding vocabulary by helping her make connections to the words improved her understanding. The success of this instruction demonstrates that she could be taught to comprehend through visual approaches.

The school's reading program not only did not fit Kathy's needs but also was incongruent with her learning style. We concluded that she needs a visual, kinesthetic approach to instruction, with opportunities for independent practice and a focus on reading strategy instruction. Instead the school is using an auditory-based program focused on word identification skills.

\section{Case 4: Stacy}

Stacy is enrolled in a sixth-grade class in a private school. She is an avid reader and enjoys trips to the local public library and bookstores. She is actively engaged in many extracurricular activities; for example, she is active in her Girl Scouts troop and enjoys playing softball and basketball.

When asked about the type of reading instruction provided in her school, Stacy responded, "I read chapter books in class." Also, "no one really reads with me, and it's not like a one-on-one thing." She further added, "I like working on the computer." When asked about the kinds of materials she likes to read, her response was, "I like to read in math, because there isn't much to read."

According to her parents, areas that present difficulty for Stacy include "comprehension and motivation." Throughout the parent interview, her parents made numerous references to her difficulty with comprehension. They commented that although "Stacy has a positive self-concept about her reading," she experiences difficulty with comprehension. In addition her parents expressed concern that there is a "disconnect between Stacy's reading needs and what she receives." She has been very frustrated with many Ds on her report card, and her parents are at a loss for how to help her. The principal, who is also her language arts teacher, tries to tutor her after school when he has time.

From the assessments administered, we determined that Stacy can read words on the sixth-grade level, but she only comprehends on a first-grade level, having difficulty with any questions except simple recall. She enjoys reading and has a positive self-concept as a reader but does not think the instruction she receives is motivating. When assessed, she applied no strategies consistently. When asked about what reading strategies she has been taught, she shared that she has not been taught strategies.

Her instruction in the reading clinic included a systematic approach teaching one reading strategy at a time. She responded well to visual organizers that she could design and use herself to learn the strategy. Her reading comprehension level improved considerably with only 10 hours of instruction focused on learning one strategy.

In Stacy's school, reading is being used and not taught. There are no reading classes or reading specialists available, and the principal is only giving extra help sporadically when Stacy struggles to read for her assignments. She needs a more systematic approach to how to use strategies to understand what she reads.

\section{Case 5: Sam}

Sam is enrolled in a sixth-grade class in an urban public school. He enjoys sports and plays basketball, football, kickball, and baseball. His father describes him as a gifted athlete, to whom basketball comes easily. Sam makes good grades in school, maintaining an $88 \%$ average across all subjects. However, he received additional one-on-one support from a reading specialist two days a week when he was in the fifth grade.

Sam reported that he does not like to read for pleasure because he lacks understanding of what he reads. He believed that reading was easier when he was 6 years old and there were pictures to help him. $\mathrm{He}$ described his reading class as consisting of a drill, 
talking about something, reading a book, and finally taking tests on the book- "questions and a lot of stuff." He likes reading class best when they get to talk about what they read. He indicated that the reading strategies he uses are reading aloud, rereading, and taking notes. When asked when he likes reading the most, he responded, "When I like the book and it's about what I like...like basketball."

Sam's father expressed concern about his son's reading based upon observations made at home. $\mathrm{He}$ stated that Sam has always tested on grade level for reading in school, but he believes that Sam has a limited vocabulary, difficulty understanding what he reads, and difficultly retelling important story events. Sam's parents limit his time on the computer at home and allow him to use it mostly for homework. His father explained that when Sam goes on the computer, he downloads music for his iPod or uses it for research for school, but he does not surf the Internet. Sam stated that on weekends, he likes to play Nickelodeon games on the computer. According to his father, Sam has difficulty with comprehension, whether he is reading a print document or reading online. He believes that Sam does not understand the value in working at something that takes time and effort. He would like Sam to understand that when you value something, "you have to put the work behind it in order to become good at it." Although he did not provide any specifics, Sam's father expressed some concern about the reading instruction his son receives in school, stating, "It's not engaging. Learning is not a rote process. It's getting people excited."

From the assessments administered to Sam, we determined that his reading comprehension is at a fifth-grade level. He has strong phonics and decoding skills, uses before-reading strategies effectively, is motivated to succeed, and has a positive attitude toward school and the reading clinic. His needs include vocabulary development and during- and after-reading strategies, as reported by his parents.

The concern with Sam is that he is reading below level but testing on level on the state tests. As a result, he is not receiving specific reading instruction to improve his comprehension but is participating in a reading class where he is just reading, answering questions, and taking tests. The school system that he is in uses tests from the language arts textbooks, which assess knowledge of the story rather than comprehension strategies, and the school system does not have reading specialists in the schools. In this case, assessment aligned with the state standards would help the school understand Sam's needs better. As he progresses to high school, content area reading will present more challenges to him.

Sam's reading clinic instruction focused on making connections and self-questioning to improve his reading comprehension. He learned to use visual organizers and sticky notes to help him comprehend any type of reading selection. Additionally he learned practical strategies, such as games and webs, to help him learn new vocabulary. His clinic teacher reported that he learned very quickly and was able to use these strategies independently.

\section{Case 6: Leon}

Leon is enrolled in the seventh grade in an urban school. He has never been retained and has been placed in gifted and talented classes in the past. He has never received extra reading help in school, and the school does not have a reading specialist. On the state reading achievement test, he has always scored in the advanced category. He likes to play football and basketball. He enjoys playing games on the computer but shared that he sometimes struggles with reading the directions of the games; however, he has taught himself to work through this. He also enjoys reading when he can choose what he reads.

Leon shared that he struggles with reading aloud because he had a stuttering problem when he was younger. Unfortunately reading aloud is often done in his classes. Reading in science class presents the biggest problems for him. He expressed that "before I started the [reading] clinic, I really didn't understand what I read. Yes, I feel like I can understand a lot more than I did before."

Leon's mother related that, although he always scored high on the state assessments, she feels strongly that he has a problem with comprehending what he reads. She worries that the school does not do "a lot of in-depth study and research" and that her son is not learning "higher order thinking." She attributes this to the large class sizes and "new teachers who come 
and go." She believes her son needs more of a handson approach through which he will learn to "synthesize and evaluate all levels of thinking."

Leon's mother also shared a concern that the school does not provide tips on how parents can help or even explain what type of curriculum they are using. She expressed shock that when she applied for her son to go to private school, they recommended that her son repeat seventh grade. Her son's progress in the reading clinic encouraged her because he voluntarily and enthusiastically did the work and "is finally starting to put things together."

In assessing Leon's reading ability in the reading clinic, the teacher found his reading comprehension level was three grades below his grade level on two different assessments. The only strategies he was able to verbalize were sounding out and predicting. Although his word identification was higher than his comprehension, it was still two grade levels below his actual grade level.

Leon read better orally than silently but is very self-conscious reading aloud because of his early stuttering. His self-concept as a reader was higher than his value of reading when he started working at the reading clinic. He responded best when his interests were considered in selecting reading materials. When comprehension strategy instruction included handson activities, such as visual organizers and writing notes while reading, he did well, which his mother predicted.

Leon is in the same school system as Sam. Again, the tests used quarterly in the school were developed by the book publisher and test knowledge of the stories. In many cases this knowledge is very literal, so the school has not actually realized that Leon struggles with comprehension. Like Sam, Leon did well on the state reading assessments though he comprehends below grade level.

\section{Case 7: Andrew}

Andrew is a 14-year-old boy enrolled in eighth grade in suburban public school who planned to attend a magnet high school the following year. At the time of our interviews, he was participating for the second time in the reading clinic. $\mathrm{He}$ is a student athlete, playing both football and basketball. His mother reported that he makes good grades in school but often loses motivation toward the end of the school year. Struggling with reading is not a new phenomenon for Andrew; he worked with a reading specialist from grades 1 through 6 and, in addition to attending the reading clinic, met with a private reading tutor every Saturday.

Andrew loves to discuss sports, read about sports, and buy athletics-themed clothing online. He considers himself an "OK" reader and is able to articulate his main comprehension strategy, which is to go back and reread. He articulated specific difficulty with remembering what he reads, particularly in language arts class. He further elaborated that the teacher picks the stories and books, so students do not have any voice in what they read; he shared that he would prefer to have some choice in reading selections. He related that sometimes the teacher facilitates class discussion, but students mostly answer questions about reading. Overall, he was frustrated with his teachers. When asked what teachers might do to help him become a better reader, he replied, "start teaching and explaining things."

Although Andrew said that he struggled particularly in language arts, his mother reported that he struggled with reading and understanding in science. She expressed frustration with the school and described how she seeks out alternative instruction for Andrew. She enrolled him in a magnet high school for the following year but is concerned that he will struggle because he is behind his peers. She explained that Andrew could only bring home his history and math textbooks, and the teachers rarely communicated with her. "They are just not doing anything, and it is sad. They don't call me. They don't tell me anything. I don't care if you have 50 kids in your class. Ten out of 50 may be doing well. Let me follow up. I don't think they have phone numbers, because they never have called me."

From the assessments administered, we found that Andrew was indeed reading below grade level and was particularly struggling with comprehension. His word recognition was strong. His identified needs include vocabulary, comprehension strategies while he is reading, and writing development. 
In the reading clinic, Andrew learned comprehension strategies using sticky notes and visual organizers. His comprehension improved during his first experience in the reading clinic, which he was able to demonstrate when he returned. His mother shared that she was pleased that he was still using strategies from the first reading clinic and could explain them to her.

Andrew is also not in a reading program that teaches comprehension skills in his school. In language arts class, the students use an anthology of literature and respond to questions about the stories. Additionally strategic instruction of comprehending what is read in the content areas is not being done.

\section{What We Learned}

We found that reading comprehension was below level for all students in the study, but none of them were receiving intervention focused on comprehension. Tamika and Kathy received intervention focused on phonics in scripted programs, which were not aligned with their needs or learning strengths. For the other students, the problem was more a lack of any comprehension instruction. The students told us they just read and answered questions in their language arts classes.

The students also all expressed concerns that they had the most problems reading in content area classes and received no help with strategies on how to understand those materials. The students' low comprehension levels were in expository text. Since most of the reading they will do during the rest of their schooling and in future employment will be in this type of text, instruction needs to focus on strategies for understanding its different types. In contrast, the students shared that they were able to understand what they chose to read and what they read on the computer. Giving choices and using online resources may also help improve the understanding of content area reading.

The parents in this study understood the problems their children were experiencing but expressed frustration that the schools communicated very little with them. Some parents also voiced concern that their sons or daughters tested on or above grade level on state reading achievement tests but were struggling to understand what they read. The parents in this study had many excellent perceptions that could help school systems understand how to reach adolescents.

Our research team recommends focusing on the adolescents' needs rather than just putting them in a program. Instruction that focuses on needs requires that funds be spent on hiring qualified reading specialists instead of buying one-size-fits-all programs. The instruction provided by reading specialists should include more self-selected reading to help stu-
The students also all expressed concerns that they had the most problems area classes and received no help with strategies on how to understand those materials. reading in content dents see the benefits of improv-

ing reading in something they want to read; ways to critically think about text in both language arts and other content areas; more before-, during-, and afterreading comprehension instruction; and, as suggested by the International Reading Association and the National Middle School Association (2002), "wellprepared...teachers who integrate individualized reading instruction within their content areas" (p. 2). Finally, ways to use computers to enhance instruction needs to be more thoughtfully included. Our research supports the conclusions of Deshler, Palincsar, Biancarosa, and Nair (2007) that if "adolescents can read the words, comprehension naturally follows" (p. 14) and that technology could be used in many ways to help struggling adolescent readers.

\section{Limitations Provide Opportunities}

The investigators realize that from these seven case studies, we cannot generalize beyond these students. We do recognize, though, that these students and their parents have important stories to tell. The parents of these students cannot be considered representative of all parents of adolescents because they actively sought their child's participation in the reading clinic. How many parents do not know where to turn or how to express their concerns?

The student snapshots, therefore, provide the chance to prompt administrators and teachers to examine the literacy instruction in their schools as 
well as their home-school communication methods. Additionally the snapshots may help to break down the stereotypes often expressed by secondary educators that parents do not care about being involved with what their students are doing in middle schools.

\section{Suggestions for Future Research}

Rampey, Dion, and Donahue (2009) reported that "the average reading score for 17-year-olds was not significantly different from that in 1971" (p. 1). The literacy demands of the workplace today, though, are very different from what they were in 1971. Kamil and colleagues (2008) suggested that "structural barriers at the middle and high school levels" (p. 1) interfere with improving the literacy levels of adolescents. Some of the barriers that they discussed are avoiding reading in the content areas and lack of effective reading instruction to meet the needs of the learners. We would like to add to their concerns the lack of using technology effectively to expand learning, the partnering with parents to meet the needs of the students, and the need for qualified reading specialists in schools who can assess and teach to the needs of students rather than using scripted programs.

We hope that our research will open discussions of how to meet these needs by listening to the voices of the teens in this study and their parents. Additionally we welcome other researchers and administrators to use our cases to open conversations. Finally we recommend more research about what changes need to be considered in schools to support adolescents in learning the literacy strategies that they will need to meet the literacy needs of the future.

\section{Note}

If you would like to dialogue with the authors about this study, visit our blog, Literacy Needs of Adolescents, at adolescentliteracy.wordpress .com.

\section{References}

Alvermann, D.E. (2003). Seeing themselves as capable and engaged readers: Adolescents and re/mediated instruction. Naperville, IL: Learning Point.

Biancarosa, G., \& Snow, C.E. (2004). Reading next-A vision for action and research in middle and high school literacy: A report from Carnegie Corporation of New York. Washington, DC: Alliance for Excellent Education.
Bogdan, R., \& Biklen, S. (2002). Qualitative research for education: An introduction to theories and methods (4th ed.). Boston: Allyn \& Bacon.

Conley, M.W., \& Hinchman, K.A. (2004). No Child Left Behind: What it means for U.S. adolescents and what we can do about it. Journal of Adolescent \& Adult Literacy, 48(1), 42-50. doi:10.1598/JAAL.48.1.4

Deshler, D.D., Palincsar, A.S., Biancarosa, G., \& Nair, M. (2007). Informed choices for struggling adolescent readers: A researchbased guide to instructional programs and practices. Newark, DE: International Reading Association.

Engelmann, S., Carnine, L., \& Johnson, G. (1999). Corrective reading. Columbus, OH: SRA/McGraw-Hill.

Greene, J.F. (1996). Language! The comprehensive literacy curriculum (3rd ed.). Frederick, CO: Sopris West.

Guthrie, J.T., \& Humenick, N.M. (2004). Motivating students to read: Evidence for classroom practices that increase reading motivation and achievement. In P. McCardle \& V. Chhabra (Eds.), The voice of evidence in reading research (pp. 329-354). Baltimore: Paul H. Brookes.

International Reading Association \& National Middle School Association. (2002). Supporting young adolescents' literacy learning: A joint position statement of the International Reading Association and the National Middle School Association. Newark, DE; Waterville, $\mathrm{OH}$ : Authors.

Kamil, M.L, Borman, G.D., Dole, J., Kral, C.C., Salinger, T., \& Torgesen, J. (2008). Improving adolescent literacy: Effective classroom and intervention practices: A practice guide (NCEE Publication No. 2008-4027). Washington, DC: National Center for Education Evaluation and Regional Assistance, Institute of Education Sciences, U.S. Department of Education. Retrieved August 12, 2009, from ies.ed.gov/ncee/ wwc/pdf/practiceguides/adlit_pg_082608.pdf

Leslie, L., \& Caldwell, J. (2006). Qualitative reading inventory-4 (4th ed.). Boston: Allyn \& Bacon.

Lexia Learning Systems. (2004). Lexia Comprehensive Reading Test, version 1.3. Concord, MA: Author.

Moore, D.W., Bean, T.W., Birdyshaw, D., \& Rycik, J.A. (1999). Adolescent literacy: A position statement for the Commission on Adolescent Literacy of the International Reading Association. Newark, DE: International Reading Association.

National Endowment for the Arts. (2007). To read or not to read: A question of national consequence (Research Report No. 47). Retrieved August 12, 2009, from www.arts.gov/research/ ToRead.pdf

National Governors Association. (2005). Reading to achieve: A governor's guide to adolescent literacy. Retrieved February 19, 2008, from www.nga.org/Files/pdf/0510GOVGUIDE LITERACY.PDF

Pitcher, S.M., Albright, L.K., DeLaney, C.J., Walker, N.T., Seunarinesingh, K., Mogge, S., et al. (2007). Assessing adolescents' motivation to read. Journal of Adolescent $\&$ Adult Literacy, 50(5), 378-396. doi:10.1598/JAAL.50.5.5

Rampey, B.D., Dion, G.S., \& Donahue, P.L. (2009). NAEP 2008 trends in academic progress (NCES Report No. 2009-479). Washington, DC: National Center for Education Statistics, U.S. Department of Education. 
Santa, C.M. (2006). A vision for adolescent literacy: Ours or theirs? Journal of Adolescent \& Adult Literacy, 49(6), 466-476. doi:10.1598/JAAL.49.6.2

Pitcher, Martinez, Dicembre, Fewster, and McCormick teach at Towson University, Maryland, USA; e-mail spitcher@towson.edu,gmartinez@towson.edu, edicembre@towson.edu,dfewster@towson.edu, and mkmccormick@towson.edu. 
Copyright of Journal of Adolescent \& Adult Literacy is the property of International Reading Association and its content may not be copied or emailed to multiple sites or posted to a listserv without the copyright holder's express written permission. However, users may print, download, or email articles for individual use. 